\title{
Criminality and economic growth province in Indonesian
}

\author{
Nairobi*; Muhammad Afif Firdaus; Fadeli Yusuf Afif
}

Faculty of Economics and Business, Universitas Lampung, Indonesia

*To whom correspondence should be addressed. Email: nairobi@feb.unila.ac.id

\begin{tabular}{|l|l|l|l|l|}
\hline DOI: & Received: & Revised: & Accepted: & Published: \\
10.22437/ppd.v9i4.13408 & 21.06 .2021 & 20.08 .2021 & 28.09 .2021 & 31.10 .2021 \\
\hline
\end{tabular}

\begin{abstract}
The decline in economic growth, which is offset by the increasing number of people and the lack of availability of jobs, has caused more people to be affected and involved in non-crime activities based on the crime rate (CR). This study aims to analyze the effect of crime rates on provincial economic growth in Indonesia in 2011-2020. The variables used are economic growth, crime rates, investment, labor, and initial growth. The method used is the Fixed Effect Model. The results show that the higher the crime rate impacts the decline in economic growth, further increase in investment and labor will encourage economic growth. In contrast, the initial growth shows that the economy of poor provinces grows slower than rich provinces.
\end{abstract}

Keywords: Crime rate, Economic growth, Initial growth, Investment, Labor.

JEL Classification: O11, O47, R11

\section{INTRODUCTION}

Crime is an unacceptable phenomenon in society. The history of crime begins with the origin of human history in this world. There is no universal and permanent definition of crime. In different eras, the definition of crime is also different. In other words, crime is an instrumental act of violating the law carried out without justification and sanctions as a violation by the state. In criminology, the tendency of individuals to commit crimes can be seen from a biological perspective, a sociological perspective, and other perspectives. This science also gives two meanings to crime, namely juridically and sociologically. Juridically, Bonger (Kummar, 2013) argues that crime means a social cycle that consciously receives a reaction from the state in the form of suffering and then reacts to legal definitions regarding crime. Sociologically, crime is human behavior created by society.

Two factors can lead to crime: internal factors, which include specific and general characteristics in the sense of the individual, and external factors. Individuals' special traits include mental illness, emotional power, low mentality, and anatomy. At the same time, the general characteristics of individuals include physical strength, individual position in society, individual education, and individual entertainment (Kathena \& Sheefeni, 2017). External factors may include economic factors (price changes, unemployment, income, urbanization), religious, reading, and film factors. In general, criminals do illegal things because the thought of satisfaction is greater than their satisfaction if they follow the applicable law (Mulok et al., 2016). 
The performance of a country can be measured by economic growth. Economic growth is one of the indicators used to measure the economic performance of a country. Economic growth is the main goal of developing countries. The success of the government's performance and its institutions tends to be measured by the economic growth generated (Krugman \& Wells, 2018). According to Mankiw (2019), economic growth increases output in the long run. He also mentioned that economic growth is also related to increased "output per capita". In addition, according to Mankiw (2019), economic growth is the process of increasing the production of goods and services in community economic activities.

Kummar (2013) found a negative and statistically significant relationship between crime and economic growth in the Indian state. Simple logic suggests that criminal activity should decrease in good economic conditions. This means that the better the country's economy, the more jobs will be created, less unemployment, increased income levels, and reduced criminal activity. However, this is not always the case. On the contrary, what is true is that criminal activity tends to increase even when the economy is good. Mulok et al. (2016), in their research, found strong evidence of cointegration in the long term where the impact of economic growth on crime in the long term was found to have a positive and statistically significant relationship. In the short term, the bidirectional cause between crime and economic growth was also significant. This means that their research is consistent with economists' arguments that the better the economic activity in a country, the more crime it will cause, and vice versa when economic conditions are bad.

Previous research has concluded that countries are experiencing an economic downturn due to crime. Islam (2014) conducted a study to examine the relationship between GDP and crime from 1960 to 2013. He started his research by experiencing difficulties in testing the hypothesis that macroeconomic factors greatly influence crime trends. In his research, he found that crime affects economic factors and an interdependent relationship between the two.

However, according to Levine \& Renelt (1992), as a determinant of economic growth, a study must use control variables, which control variables are variables that have been widely recognized as determinants of economic growth. Control variables consist of, among others, the initial level of GDP, population growth, and investment. Based on Levine and Renelt's economic growth model, the author conducted a study on the relationship between crime and the economy in Indonesia using panel data from 31 provinces. Researchers make Indonesia the object of research because Indonesia is a developing country where economic growth is an indicator of the success or decline of a country's economy; economic growth is also an indicator of people's welfare.

\section{METHODS}

The variable used in this study is economic growth (EG) in 31 provinces of Indonesia obtained from the Central Statistics Agency (BPS). The data taken is secondary data in the form of a combination of time series data with cross-individual data (cross-section) from 2011-2016 in the form of a percentage (\%).

The dependent variable in this study is economic growth (EG). To measure the variable economic growth is proxied through the value of per capita GRDP growth based on constant prices. The independent variable in this study consists of the Crime Rate (CR), which is a number that indicates the level of crime vulnerability in a particular area. The data used to obtain the crime rate for 31 provinces in Indonesia was 
obtained from the Central Statistics Agency (BPS) during the period 2011-2016 in percentage form $(\%)$.

Investment (I) uses the ratio of realized domestic investment to Gross Regional Domestic Product (GRDP) based on 2010 price constants obtained from the Central Statistics Agency (BPS), Manpower (L) uses data on the ratio of the population aged 15 years and over who work the population (EPR) which includes the labor force is obtained from the Central Statistics Agency (BPS), and the Initial Growth (IGt-1) data on economic growth taken from one year before the academic year is obtained from the Central Statistics Agency (BPS). follows:

This study uses an analysis of the economic model of Levine \& Renelt (1992) as

$$
Y=\beta_{i} i+\beta_{m} M+\beta_{z} Z+\mu
$$

Where:

$\mathrm{Y} \quad=$ GRDP per capita

I $\quad=$ Growth Function Variable

$\mathrm{M} \quad=$ Researcher Interest Variables

$\mathrm{Z} \quad=$ Supporting Variables

$\mu \quad=$ Error Term

ßí = Regression coefficient of each influencing variable.

Then the model (1) is transformed into a panel data regression equation model as follows:

$$
P E_{i t}=\beta_{0}-\beta_{1} C R_{i t}+\beta_{2} P M_{i t}+\beta_{3} T K_{i t}+\beta_{4} I G_{i t-1}+\mu_{i t}
$$

This model determines the effect of Crime Rate (CR) on economic growth (EG) and other supporting variables. 1) Investment; 2) Labor; 3) Initial growth.

Information:

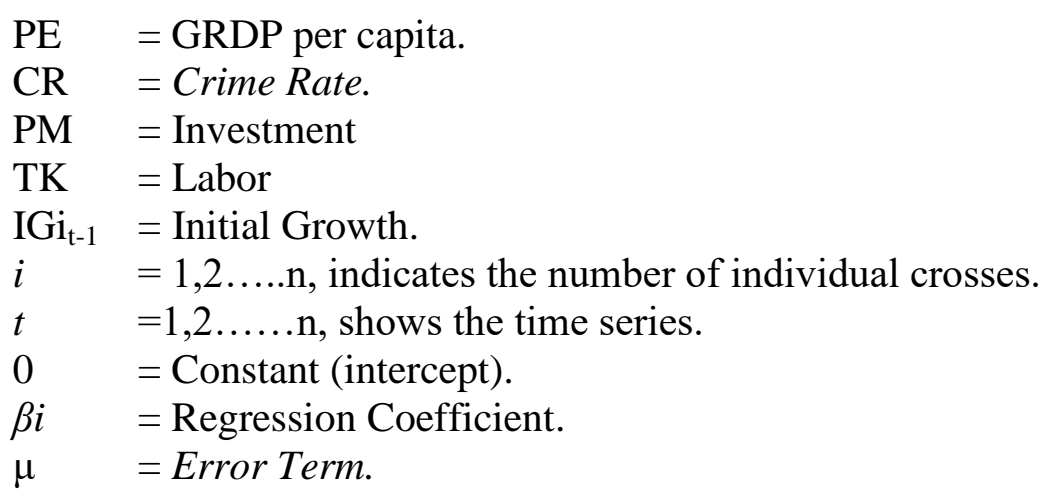

Some of the advantages of using panel data in the econometric analysis were stated by Baltagi (2005), namely, first controlling for individual heterogeneity. Panel data states that individuals, companies, places, or countries are heterogeneous. Panel data consists of quantity and time, so many other variables may be state-invariant or time-invariant, affecting the dependent variable. Panel data provides an opportunity for the treatment of each unit analyzed to be heterogeneous. Panel data is also suitable for studying the duration of economic magnitude variables such as unemployment, poverty, and inflation and can also explain the speed of response to changes in economic policy.

In the analysis with the panel data model, there are three kinds of estimation 
approach methods that are commonly used: Common Effect Model (CEM), Fixed Effect Model (FEM), Random Effect Model (REM). The Chow test chooses the analysis technique that will be used best between the fixed effect and Ordinary Least Square models. The Hausman test carried out is to choose the best analysis technique between the random effect model and the fixed effect model to be used in regression testing. If the results of the two previous tests are obtained in one test or even both tests accept H0, then a test called the Lagrange Multiplier (LM) test is carried out, which is also called the Breusch-Pagan Random Effect. However, this test does not need to be carried out if this is not the case. This test is conducted to select the best analysis technique between the common effect model and the random effect model (Baltagi, 2015).

\section{RESULTS AND DISCUSSION}

\section{Results}

Descriptive statistics provide an overview or description of data seen from the average value (mean), standard deviation, maximum, minimum, kurtosis, and slope of the distribution (skewness). The variables used are economic growth, crime rate, investment, labor, and initial growth. These variables, descriptive statistical tests were carried out with the following results:

Table 1. Descriptive statistics

\begin{tabular}{cccccc}
\hline Variable & Growth & Crime Rate & Investment & Labor & Initial Growth \\
\hline Mean & 3.89 & 0.20 & 2.06 & 94.53 & 3.91 \\
Median & 4.50 & 0.20 & 1.50 & 94.95 & 4.50 \\
Maximum & 10.60 & 0.50 & 10.00 & 98.60 & 20.60 \\
Minimum & -9.30 & 0.00 & 0.00 & 88.30 & -9.30 \\
Std, Dev, & 2.59 & 0.11 & 2.10 & 2.08 & 2.74 \\
Skewness & -1.32 & 0.26 & 1.89 & -0.75 & -0.45 \\
Kurtosis & 5.61 & 2.86 & 6.81 & 3.01 & 8.89 \\
Jarque-Bera & 178.01 & 3.76 & 3.73 & 29.22 & 459.08 \\
Probability & 0.00 & 0.15 & 0.00 & 0.00 & 0.00 \\
Observations & 310 & 310 & 310 & 310 & 310 \\
\hline
\end{tabular}

$\mathrm{N}$ or the amount of data for each valid variable is 310 , from 310 sample data on economic growth $(\mathrm{Y})$, the minimum value is -9.30 , the maximum value is 10.56 , and the mean value is 3.89 . The standard deviation value is 2.59 , which means that the mean value is greater than the standard value. The deviation of the data that occurs is low, then the distribution of the values is evenly distributed.

Based on the Chow test and Hausman test results, the best model to analyze the data in this study is the Fixed Effect (FEM) model. The Chow test is a test conducted to select the best approach model between the Common Effect Model and the Fixed Effect Model by looking at the value of the F statistical distribution. Suppose the probability value of the $\mathrm{F}$ statistical distribution is more than the specified significance level value. In that case, the model used is the Common Effect Model. If the probability value of the F statistical distribution is less than the significance level, the model used is the Fixed Effect Model (Gujarati \& Porter, 2013). 
Table 2. Panel data regression results for economic growth bound variables

\begin{tabular}{lccc}
\hline Variable & CEM & FEM & REM \\
\hline Constant & -17.861 & 12.388 & 17.861 \\
Crime Rate & $(0.007)^{*}$ & $(0.000)^{*}$ & $(0.001)$ \\
(CR) & -4.39339 & -0.561 & -4.39339 \\
Investation & $(0.001)^{*}$ & $(0.000)^{*}$ & $(0.000)^{*}$ \\
(PM) & -0.045 & 0.026 & -0.045 \\
Labor & $(0.507)$ & $(0.004)$ & $(0.421)$ \\
(TK) & 0.234 & 0.752 & 0.234 \\
Initial Growth & $(0.001)^{*}$ & $(0.000)^{*}$ & $(0.000)^{*}$ \\
(IG) & 0.149 & -0.148 & 0.149 \\
\hline \multirow{2}{*}{ Chow test } & $(0.005)^{*}$ & $(0.005)^{*}$ & $(0.001)^{*}$ \\
& & 152.068 & \\
Hausman test & & $(0.000)^{*}$ & \\
Note: $*)$ significant at $=5 \%$ and $* *)$ significant at $=10 \%$ & 169.927 & \\
& & &
\end{tabular}

The regression results show that the Fixed Effect Model (FEM) is the best model used. The crime rate has a significant and negative effect on the economic growth of provinces in Indonesia. This shows that an increase in the crime rate will reduce economic growth, then investment and labor have a significant and positive effect on economic growth. Initial growth has a significant and negative effect on the economic growth of provinces in Indonesia. The negative sign indicates that the economy in underdeveloped provinces grows more slowly than in more developed provinces.

\section{Discussion}

\section{The crime rate on economic growth}

The calculation results show that the crime rate has a negative and significant effect on economic growth in Indonesia's 31 (thirty-one) provinces. A high crime rate (CR) can disrupt or reduce investment entering a region or country. Because if the crime rate in an area is high, it will disrupt the running of the business and investment environment, which results in doubts in making investments in that region, which means it can reduce economic growth in a region or country. So we can assume that crime affects economic growth.

Kummar (2013) found a negative and statistically significant relationship between crime and economic growth in the Indian state. Simple logic suggests that criminal activity should decrease in good economic conditions. This means that the better the country's economy, the more jobs will be created, less unemployment, increased income levels, and reduced criminal activity. However, this is not always the case. On the contrary, what is true is that criminal activity tends to increase even when the economy is good.

Islam (2014) conducted a study to examine the relationship between GDP and crime from 1960 to 2013. He found that macroeconomic factors have a major influence on crime trends. In his research, he found that crime affects economic factors, and there is an interdependent relationship between the two. This means that their research is consistent with economists' arguments that the better the economic activity in a country, the more crime it will cause, and vice versa when economic conditions are bad.

In his research, Ahmad et al. (2014) and Rahman \& Prasetyo (2018) found no statistically significant effect of crime on economic growth. The regression analysis 
results failed to support the hypothesis that crime has a statistically significant negative impact on economic growth. Although crime does not have a significant effect, it still changes some of the determinants, such as higher population growth than economic growth while investment contributes less.

\section{Investment in economic growth}

The calculation results show that investment has a positive and significant effect on economic growth. Investment is essentially the first step in economic development activities. The investment dynamics affect the level of economic growth and reflect the rampant sluggish development. To grow the economy, each country seeks to create a climate that can encourage increased investment and impact economic growth in a positive direction.

Regional investment has been empirically proven to encourage economic growth through national income. In addition, the results of this study are by the results of research conducted by Levine \& Renelt (1992), which states that there is a strong relationship between the variable identity of capital (initial capital) which is realized by the level of investment and economic growth. Regional investment has been empirically proven to encourage economic growth through national income.

\section{Labor on economic growth}

The results show that an increase in the workforce will positively increase economic growth. An increase in labor means an increase in output per person employed, commonly known as labor productivity. The increase in labor productivity is the main contributor to increasing economic growth.

Sani et al. (2018) and Levine \& Renelt (1992) state that the population manifested into the workforce will always have a positive and significant effect on economic growth in a region. Labor is a potential input that can be used as a production factor to increase the production of a company household. The number of workers directly involved in various sectors of the economy has given a strong influence in encouraging economic growth. The workforce that continues to increase from year to year if accompanied by an increase in the quality of human resources will be a force in encouraging the development of strong economic growth. In addition, the workforce also requires special attention such as requiring additional investment. The incoming investment is expected to open up job opportunities so that it can reduce the level of unemployment which can later have an impact on reducing the crime rate.

\section{Initial growth on economic growth}

In addition, the results of the Initial Growth regression show a negative sign, which means that there is a divergence in economic growth in 31 (thirty-one) provinces in Indonesia for the period 2011-2016. This shows that some provinces that are lagging or are still underdeveloped have not been able to catch up with those that have developed.

This shows that some provinces are lagging or are still not developed and have not succeeded in catching up with provinces that are already developed, from an economic and development perspective. This result also follows the research conducted by Levine \& Renelt (1992), which shows that initial growth has an effect and has a significant impact on economic growth. 


\section{CONCLUSIONS AND RECOMMENDATIONS}

\section{Conclusions}

This study indicates that an increase in the crime rate will suppress the economic growth of provinces in Indonesia. It is well recognized in public policy debates that crime undermines economic growth. Crime undermines the rule of law, reduces perceptions of security in property rights, and deters new investment from entering, leading to a decline in economic growth. The effect of crime on the economy is visible, especially in that violent crimes are more common in developing countries, especially in Indonesian society. This shows that an increase in the crime rate will reduce economic growth, then an increase in investment and labor will impact an increase in economic growth. Initial growth is divergent in that the economy is lagging provinces grows more slowly than in more developed provinces.

\section{Recommendations}

The government should review and add criminal statistical indicators that highlight aspects in the economic field. Such as making special data in the field so that it can be used in research in the economic field to be used as a reference for making policies. The government should try to reduce the unemployed workforce by adding or opening a lot of jobs. The government should provide convenience in terms of licensing both in terms of time and costs that will be charged to investors, both domestic and foreign investors.

\section{REFERENCES}

Ahmad, A., Ali, S., \& Ahmad, N. (2014). Crime and Economic Growth in Developing Countries: Evidence from Pakistan. J. Basic. Appl. Sci. Res, 4(4), 31-41.

Baltagi, B. H. (2005). Econometric Analysis of Panel Data. In John Wiley \& Sons Ltd (3th ed., Vol. 5, Issue 7). John Wiley \& Sons Ltd. https://doi.org/10.3109/00498257509056115

Baltagi, B. H. (2015). The Oxford Handbook of Panel Data. Oxford University Press.

Gujarati, D. N., \& Porter, D. . (2009). Single-equation regression models. In Introductory Econometrics: A Practical Approach (5th ed.). Douglas Reiner.

Islam, A. (2014). Economic growth and crime against small and medium sized enterprises in developing economies. Small Business Economics, 43(3), 677-695. https://doi.org/10.1007/s11187-014-9548-6

Kathena, I. N., \& Sheefeni, J. P. S. (2017). The Relationship Between Economic Growth and Crime Rates in Namibia. European Journal of Basic and Applied Sciences, 4(1), 51-62.

Krugman, P., \& Wells, R. (2018). Macroeconomics (Fifth Edition). Worth Publishers.

Kummar, S. (2013). Crime and economic growth: evidence from India. Munich Personal RePEc Archive, 48794, 1-24. https://mpra.ub.unimuenchen.de/id/eprint/48794

Levine, R., \& Renelt, D. (1992). A sensitivity analysis of cross-country growth regressions. American Economic Review, 82(4), 942-963. https://doi.org/10.2307/2117352

Mankiw, N. G. (2019). Macroeconomics, 10th Edition. In Worth Publishers.

Mulok, D., Lily, J., Kogid, M., \& Asid, R. (2016). The Relationship between Crime and Economic Growth in Malaysia: Re-Examine Using Bound Test Approach. Malaysian Journal of Business and Economics, 3(1), 15-26. 
https://doi.org/10.1063/1.4968159

Rahman, Y. A., \& Prasetyo, A. D. (2018). Economics and Crime Rates in Indonesia. Jejak, 11(2), 401-412. https://doi.org/10.15294/jejak.v11i2.16060

Sani, R. M., Sambodo, H., \& Bambang, B. (2018). The Effect of Human Capital, Labors, and Capital on Economic Growth in Barlingmascakeb. Eko-Regional Jurnal Pengembangan Ekonomi Wilayah, 13(2), 60-68. https://doi.org/10.20884/1.erjpe.2018.13.2.1172 